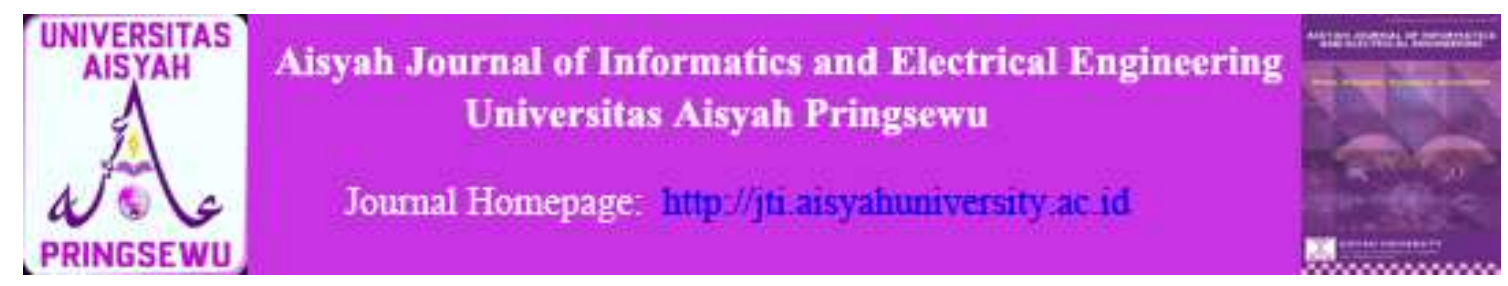

\title{
PERANCANGAN SISTEM APLIKASI UJIAN ONLINE BERBASIS WEB PADA SMA NEGERI 1 KALIREJO
}

\author{
Nur Aminudin ${ }^{1}$ Irwan Susilo \\ Program Studi Teknik Informatika, Fakultas Teknologi dan Informatika \\ Universitas Aisyah Pringsewu \\ E-mail : nuraminudin.mti.ibi@gmail.com
}

\begin{abstract}
ABSTRAK
Dunia pendidikan mengalami perkembangan yang sangat pesat yang didukung oleh inovasi-inovasi yang terlahir dari perkembangan teknologi informasi, antara lain penerapan ujian online. Sistem ujian ketika ujian tengah semester maupun akhir semester masih bersifat konvensional yang artinya ujian dilakukan dengan menggunakan kertas (Paper-Based Test) yang boros kertas dan waktu. Sistem ujian online (Computer-Based Test) merupakan bagian dari sistem informasi pendidikan yang sudah menerapkan teknologi informasi dengan menawarkan efisiensi dan efektifitas. Dalam penelitian ini penulis membuat suatu sistem ujian online yang berbasiskan web pada SMA Negeri 1 Kalirejo sebagai salah satu sekolah menengah di Kecamatan Kalirejo Kabupaten Lampung Tengah. Metode pengembangan sistem ujian online berbasis website ini menggunakan prototype. yaitu bagian dari produk yang mengekspresikan logika maupun fisik antarmuka eksternal yang ditampilkan. Sistem ujian online memberikan manfaat yaitu tidak perlu melakukan pengadaan kertas ujian dan menghemat waktu untuk koreksi ujian sehingga efisiensi dan efektitas yang menjadi tujuan pembuatan sistem ujian online dapat tercapai.
\end{abstract}

Kata Kunci : Ujian Online, Sistem Aplikasi, PHP, MySQL 


\section{PENDAHULUAN}

\subsection{Latar Belakang Masalah}

Pendidikan merupakan salah satu sektor pembangunan yang selalu mendapat perhatian besar dari pemerintah dan merupakan salah satu sektor pembangunan sektor pembangunan yang sangat potensial untuk dapat diintegrasikan dengan kehadiran teknologi informasi. Dampak dari perkembangan itulah yang menyebabkan lembaga pendidikan selalu berlomba-lomba untuk dapat menghasilkan sumber daya manusia yang berkualitas dengan berusaha memberikan pendidikan yang terbaik[1].

Dunia pendidikan dewasa ini mengalami perkembangan dalam hal teknik proses pengajaran, bentuk perkembangan ini antara lain pengajaran dengan menggunakan teknologi multimedia melalui sistem online atau dengan kata lain pengajaran dan ujian melalui jaringan internet. Proses pengajaran ini telah mulai digunakan seiring dengan berkembangnya teknologi sistem informasi dan internet oleh praktisi pendidikan baik formal maupun non formal. Hal ini juga didukung oleh meningkatnya pengguna internet di Indonesia yang semakin hari kian meningkat [2].

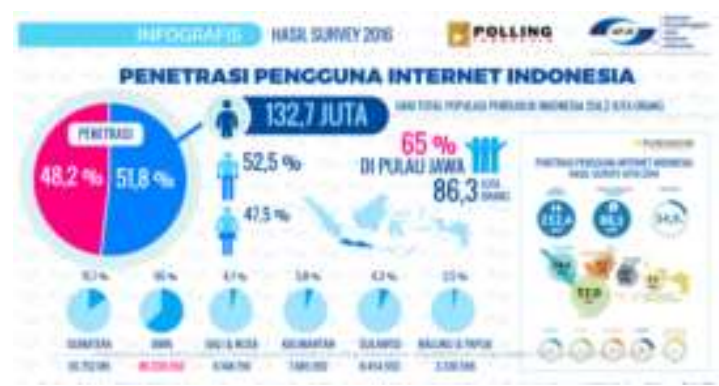

Gambar 1. Penetrasi pengguna internet Indonesia tahun 2016

Fenomena tingginya penetrasi Teknologi Informasi dan Komunikasi (TIK) di dunia termasuk di Indonesia dapat dilihat dengan data diatas, data ini ditunjukan oleh survey yang dilakukan APJII pada tahun 2016. Di Indonesia terdapat 132,7 juta pengguna jaringan internet dari total populasi penduduk Indonesia 256,2 juta orang dengan kategori laki-laki 52,5\% dan wanita $47,5 \%$. Hal ini merupakan kenaikan pengguna yang cukup pesat dibandingkan tahun 2013 yang hanya berjumlah 82 juta pengguna internet di Indonesia dan prediksi APJII pada tahun 2015 akan berkisar 139 juta [3].
Sistem ujian selama ini bersifat konvensional yang artinya ujian dilakukan dengan menggunakan kertas dan pensil dengan istilah Paper-Based Test (PBT) yang saat ini sering menimbulkan masalah sepertirawan dalam penyiapan bahan ujian, kecurangan dan scoring yang membutuhkan tenaga dan waktu yang banyak. Hal ini tentu saja kurang efektif dan efisien dibandingkan sistem ujian online.

Sistem ujian online atau biasa disebut dengan Computer-Based Test (CBT) merupakan bagian dari sistem informasi pendidikan yang sudah menerapkan teknologi informasi yang sangat erat kaitannya dengan sistem basis data sebagai media masukan dan penyimpanan data yang sesuai dengan kebutuhan para penggunanya. Sistem ujian online diharapkan mampu dalam menjawab kekurangan ujian konvesional yang selama ini diterapkan.

Dalam penelitian ini penulis ingin membuat suatu sistem ujian online yang berbasiskan web pada SMA Negeri 1 Kalirejo sebagai salah satu sekolah menengah di Kecamatan Kalirejo Kabupaten Lampung Tengah untuk dapat memudahkan para siswa dan guru dalam melakukan ujian dan mendapatkan hasil ujian yang cepat. Dalam pembuatan sistem ujian online ini penulis menggunakan bahasa Server-Side Scripting Language yaitu PHP dan MySQL.

\subsection{Rumusan Masalah}

Berdasarkan latar belakang masalah diatas maka dalam penelitian ini dirumuskan beberapa pokok permasalahan antara lain:

1. Bagaimana merubah sistem ujian konvensional menjadi sistem ujian online?

2. Bagaimana perancangan sistem informasi ujian online dan penilaian siswa pada SMA Negeri 1 Kalirejo?

3. Bagaimana hasil implementasi pengujian sistem informasi ujian online dan penilaian siswa pada SMA Negeri 1 Kalirejo?

\subsection{Tujuan}

Tujuan dari penelitian ini adalah merancang dan membuat sistem aplikasi ujian online berbasis web pada SMA Negeri 1 Kalirejo menggunakan PHP sebagai bahasa pemrograman dan MySQL sebagai basis data yang diharapkan akan mempermudah siswa-siswi dalam mengerjakan ujian seperti ujian tengah semester dan ujian akhir semester melalui soal-soal yang sudah dibuat 
melalui jaringan internet (online). Serta mempermudah para guru dalam mengolah hasil jawaban para peserta ujian online menjadi nilai yang sudah otomatis setelah siswa selesai mengerjakan soal. Tujuan lain dari pembuatan aplikasi ujian online adalah sebagai latihan Ujian Nasional Berbasis Komputer (UNBK) sehingga siswa akan lebih siap dalam menghadapi UNBK disaat ujian kelulusan.

\section{Landasan Teori}

\subsection{Definisi Sistem}

Sistem didefinisikan sebagai sekumpulan prosedur yang saling berkaitan dan saling terhubung untuk melakukan suatu tugas bersamasama. Secara garis besar, sistem informasi terdiri atas tiga komponen utama. Ketiga komponen tersebut mencakup software, hardware, dan brainware. Ketiga komponen ini saling berkaitan satu sma lain [4].

\subsection{Sistem Ujian Online}

Sistem ujian adalah sebuah sistem terintegrasi, sistem manusia mesin, untuk menyediakan dan mengadakan ujian secara lebih cepat dan efektif sehingga dapat diketahui mutunya. Sistem ini memanfaatkan perangkat keras dan perangkat lunak komputer, prosedur manual, dan basis data.

Dari definisi di atas terdapat beberapa kata kunci yaitu :

a. Berbasis komputer dan Sistem Manusia Mesin

1. Berbasis komputer : perancang harus memahami pengetahuan komputer serta pemrosesan data dan informasi

2. Sistem manusia mesin : ada interaksi antara manusia sebagai pengelola dan mesin sebagai alat untuk memroses data dan informasi. Ada proses manual yang harus dilakukan manusia dan ada proses yang terotomasi oleh mesin. Oleh karena itu diperlukan suatu prosedur/manual sistem.

b. Sistem basis data terintegrasi adanya penggunaan basis data secara bersama-sama (sharing) dalam sebuah database khusus.

c. Mengetahui Mutu Data dan informasi yang diolah dan dihasilkan, digunakan untuk mengetahui mutu dari hasil ujian [5].

\subsection{Definisi $W e b$}

WWW (World Wide Web) atau biasa disebut dengan web merupakan salah satu sumber daya internet yang berkembang pesat. Saat ini, informasi web didistribusikan melalui pendekatan hyperlink, yang memungkinkan suat teks, gambit, ataupun objek yang lain menjadi acuan yang membuka halaman-halaman web yang lain. Dengan pensdekatan hyperlink ini, seseorang memperoleh informasi dengan meloncat dari suatu halam ke halaman lain [6].

\subsection{Aplikasi Web}

Aplikasi web adalah aplikasi yang disempan dan di eksekusi di lingkungan web server. Setiap permintaan yang dilakukan oleh user melalui paliksi client (web browser) akan direspon melalui aplikasi web dan hasilnya akan dikembalikan lagi ke halaman user. Dengan aplikasi web, halaman yang tampil pada web browser dapat bersifat dinamis, tergantung dari nilai data atau parameter yang dimasukan oleh user [6].

\subsection{PHP}

PHP (Hypertext Preprocessor) adalah bahasa Server-side scripting yang menyatu dengan HTML untuk membuat halaman web yang dinamis. Karena PHP merupakan Serverside scripting maka sitaks dan perintah-perintah PHP akan dieksekusi di server kemudian hasilnya dikirimkan ke browser dalam format HTML. Dengan demikian kode program yang ditulis dalam PHP tidak akan terlihat oleh user sehingga keamanan halaman web lebih terjamin. PHP dirancang untuk membentuk halaman web yang dinamis yaitu halaman web yang dapat membentuk suatu tampilan berdasarkan perintah terkini, seperti perintah menampilakan basis data ke halaman web [7].

\subsection{MySQL}

MySQL merupakan sistem database yang banyak digunakan untuk pengembangan aplikasi web. Alasannya mungkin karena gratis, pengelolaan datanya sederhana, memiliki tingkat keamanan yang bagus, mudah diperoleh, dan lainlain. MySQL juga dapat disebut sebagai program database server yang mampu menerima dan mengirimkan datanya dengan sangat cepat, multi user serta menggunakan perintah standar SQL (structured Query Language) [7].

\section{Metode Penelitian}

\subsection{Metode Pengumpulan Data.}

Dalam melakukan pengumpulan data yang dibutuhkan dalam penelitian ini meliputi beberapa metode antara lain :

a. Observasi adalah studi yang dilakukan secara sengaja dan sistematis, terarah dan terencana pada tujuan tertentu dengan mengamati dan mencatat fenomenafenomena yang terjadi dalam suatu kelompok orang dengan mengacu pada syarat-syarat dan aturan penelitian ilmiah. Observasi dilakukan pada SMA Negeri 1 
Kalirejo dengan melihat dan menganalisa langsung proses ujian di sekolah tersebut sehingga didapatkan kelemahan dan kekurangan dari sistem yang berjalan.

b. Wawancara merupakan metode pengumpulan data dengan jalan tanya jawab sepihak yang dilakukan secara sistematis dan berlandaskan kepada tujuan penelitian. Wawancara dibutuhkan sebagai pendukung pengambilan keputusan, serta penggalian informasi pelaksanaan ujian yang berjalan di SMA Negeri 1 Kalirejo.

c. Studi pustaka adalah segala usaha yang dilakukan oleh peneliti untuk menghimpun informasi yang relevan dengan topik atau masalah yang akan atau sedang diteliti. Dalam penelitian ini studi pustaka dilakkan dengan mengambil teori-teori dari berbagai sumber yang berasal dari buku, jurnal dan situs yang terkait dengan data dan informasi yang dibutuhkan.

\subsection{Metode Pengembangan sistem}

Metode pengembangan sistem ujian online berbasis website ini adalah menggunakan SDLC dengan pendekatan prototype. Sebuah prototype adalah bagian dari produk yang mengekspresikan logika maupun fisik antarmuka eksternal yang ditampilkan. Konsumen potensial menggunakan prototype dan menyediakan masukan untuk pengembang sebelum pengembangan skala besar dimulai. Melihat dan mempercayai menjadi hal yang diharapkan untuk dicapai dalam prototype [8].

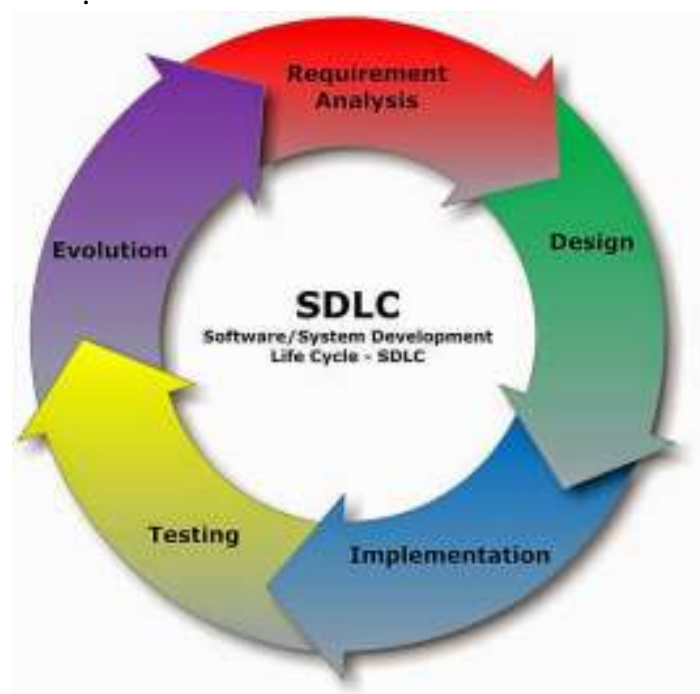

Gambar 2. Model Prototyping

Tahap-tahap dalam pengembangan prototype adalah sebagai berikut:

1. Pengumpulan kebutuhan.

Pada tahap ini merupakan tahap awal dalam membangun sebuah sistem informasi, dimana antara pemakai (user) sistem dan pengembang sistem bertemu. Pengguna dan pengembang bersama-sama mendefinisikan format seluruh perangkat lunak, mengidentifikasikan semua kebutuhan, dan garis besar sistem yang akan dibuat.

2. Membangun prototyping.

Setelah menganalisa sistem yang akan di kembangkan serta kebutuhan -kebutuhan sistem yang akan dibangun, pengembang mulai membuat prototipe Membangun prototyping dengan membuat perancangan sementara yang berfokus pada penyajian kepada pengguna (misalnya dengan membuat input dan format output).

3. Evaluasi protoptyping.

Evaluasi ini dilakukan oleh pengguna apakah prototyping yang sudah dibangun sudah sesuai dengan keinginann pelanggan. Jika sudah sesuai maka langkah 4 akan diambil. Jika tidak prototyping direvisi dengan mengulangu langkah 1, 2 , dan 3.

4. Mengkodekan sistem.

Dalam tahap ini prototyping yang sudah di sepakati diterjemahkan ke dalam bahasa pemrograman yang sesuai.

5. Menguji sistem.

Setelah sistem sudah menjadi suatu perangkat lunak yang siap pakai, harus dites dahulu sebelum digunakan. Pengujian ini dilakukan dengan White Box, Black Box, Basis Path, pengujian arsitektur dan lain-lain

6. Evaluasi Sistem.

Pengguna mengevaluasi apakah sistem yang sudah jadi sudah sesuai dengan yang diharapkan . Jika ya, langkah 7 dilakukan; jika tidak, ulangi langkah 4 dan 5.

7. Menggunakan sistem.

Perangkat lunak yang telah diuji dan diterima pengguna siap untuk digunakan.

\section{Hasil dan Pembahasan}

3.1 Diagram Konteks

Diagram konteks merupakan diagram yang mencakup masukan-masukan dasar, sistem umum dan keluaran. 


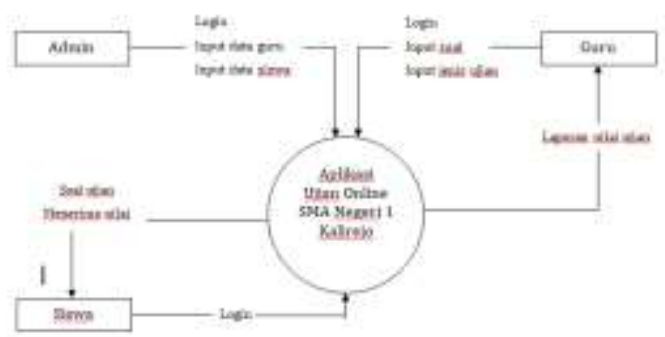

Gambar 3. Diagram Konteks

Berikut ini dijelaskan fungsi masing-masing entitas dalam sistem :

1. Entitas Administrator: administrator adalah pemelihara dan pengelola system yang menyediakan berbagai kebutuhan dari user dosen dan user siswa terhadap sistem.

2. Entitas Guru: user guru merupakan entitas eksternal sistem dalam hal memberikan bahan ujian kepada user siswa.

3. Entitas Siswa: user siswa merupakan entitas eksternal dari system yang melakukan ujian secara online berdasarkan bahan yang diberikan oleh user guru [9].

\subsection{Desain Database}

Desain database yang digunakan yaitu database pada server yang menggunakan MySQL. Database akan terhubung dengan database server sehingga segala fitur yang dilakukan akan langsung berhubungan dengan database server [10].

Desain Entity Relationship Diagram dapat dilihat pada Gambar 4.

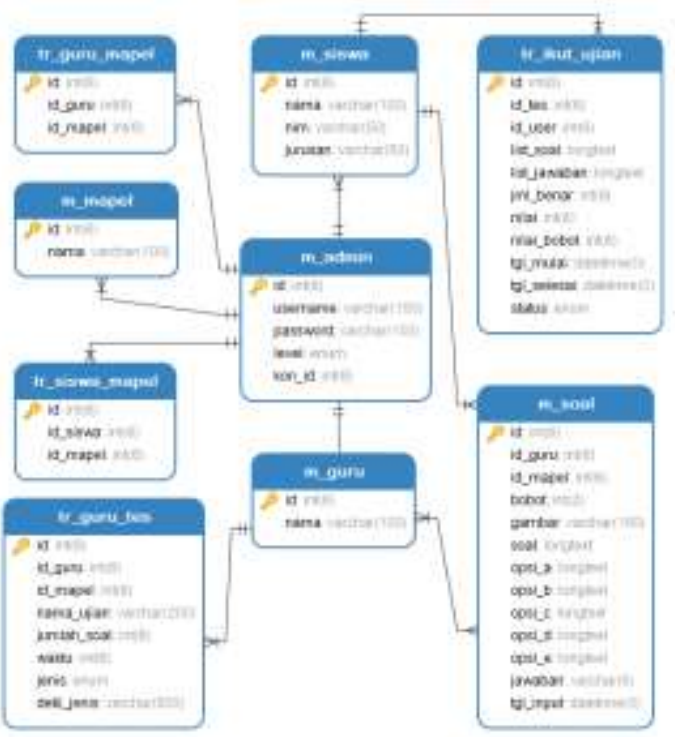

Gambar 4. Entity Relationship Diagram

\subsection{Implementasi}

Berikut adalah tampilan ujian online berbasis web yang sudah dirancang pada SMA Negeri 1 Kalirejo.
Aplikasi dimulai dengan menampilkan halaman login terlebih dahulu sebelum pengguna (siswa, guru, admin) mengakses dashboard dengan hak akses yang berbeda-beda. Setelah user melakukan login dengan menginput username dan password, maka dapat masuk ke menu dashboard, menu login dapat dilihat pada Gambar 5.

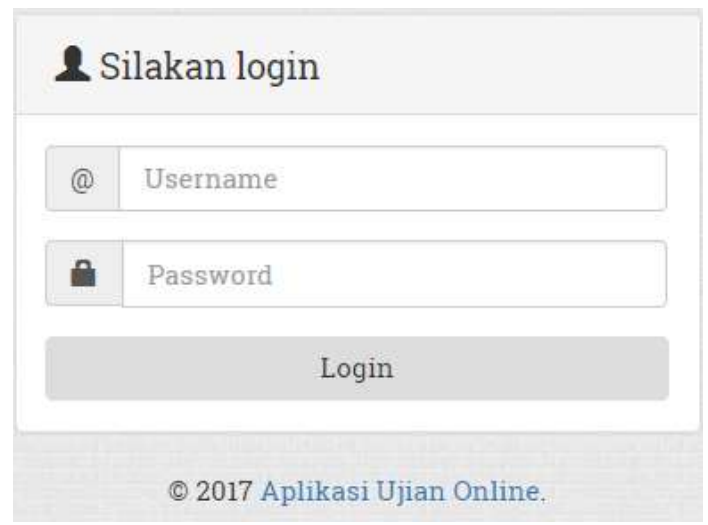

Gamba 5. Tampilan Login

Setelah pengguna admin masuk ke dalam halaman dashboard, terdapat menu pilih sesuai hak akses. Halaman dashboard admin mempunyai hak akses penuh atas semua pengaturan yang ada dalam aplikasi dengan menu data siswa, data guru, data mata pelajaran, soal dan hasil ujian. Tampilan halaman administrator dapat dilihat pada gambar 6 .

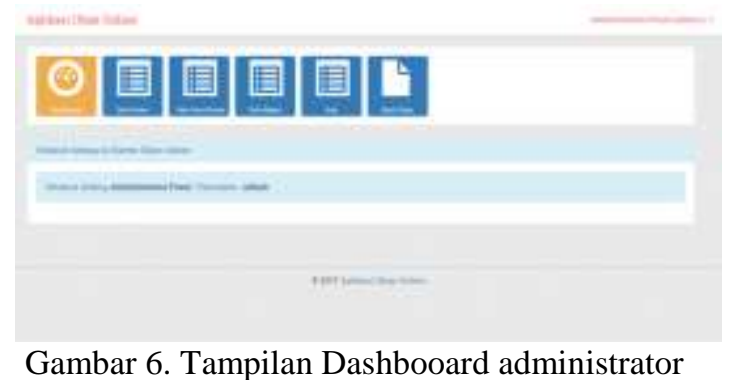

Gambar 6. Tampilan Dashbooard administrator

Data guru dimasukan oleh administrator, setiap guru memiliki mata pelajaran yang berbeda maupun sama tergantung mata pelajaran yang diampu.

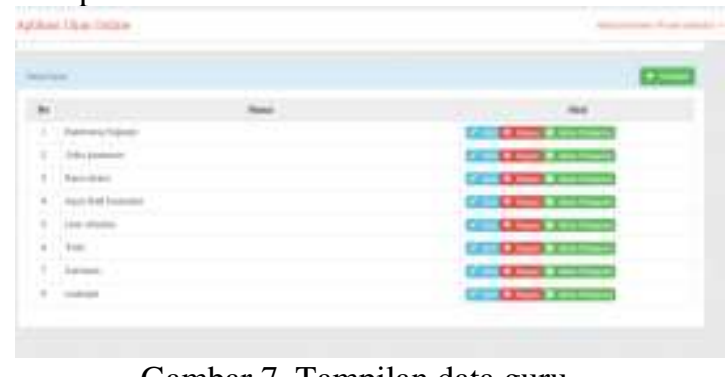

Gambar 7. Tampilan data guru 
Data siswa ditampilkan dengan nama, NIM, jurusan, serta mata pelajaran yang diambil dalam sekolah. Data mata pelajaran juga akan berelasi dengan guru dan ujian yang diadakan. Tampilan data siswa dapat dilihat pada gambar 8 .

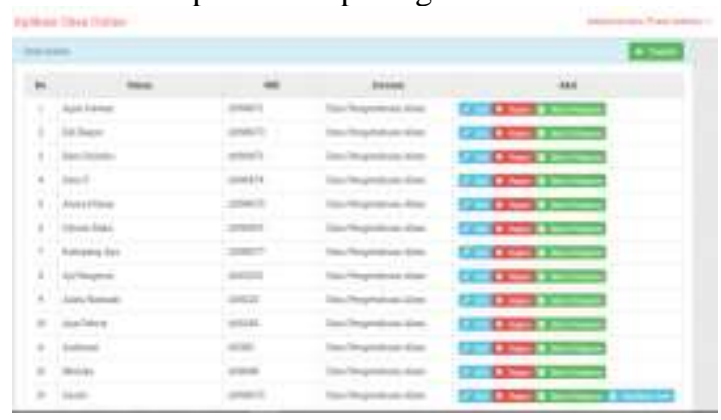

Gambar 8. Tampilan data siswa.

Halaman dashboard guru memiliki hak akses data soal serta dapat membuat soal, ujian dan menentukan ujian yang akan dilaksanakan serta hasil ujian. Tampilan dashboard guru dapat dilihat pada gambar 9 .

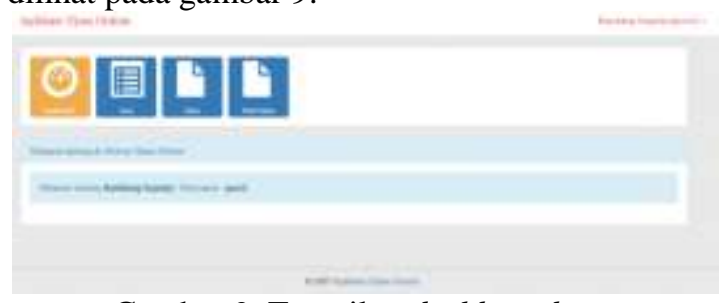

Gambar 9. Tampilan dashboard guru.

Setelah guru masuk dalam dashboard, guru dapat membuat soal dengan memilih menu data soal dan memilih tambah soal. Gambar 10 menunjukan field yang harus diisi guru dalam membuat soal, yaitu mata pelajaran, nama guru, gambar soal (bila ada), bobot soal, soal dan jawaban. Setiap guru berhak untuk membuat, mengedit dan menghapus soal yang dibuatnya.

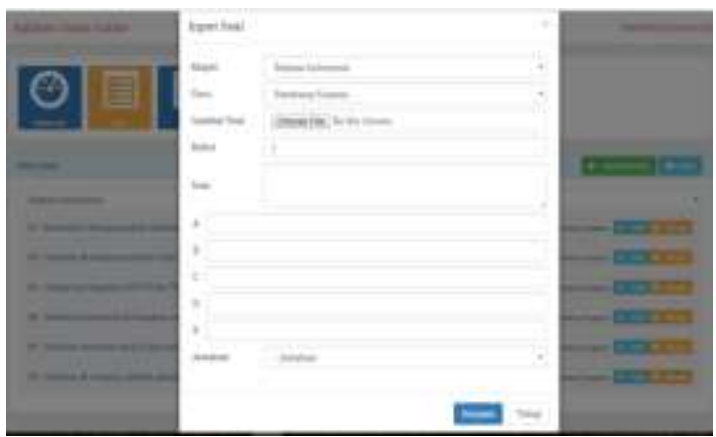

Gambar 10. Tampilan form tambah soal.

Setelah guru membuat soal ujian, terdapat daftar data soal yang telah dibuat. Data soal ditampilkan berdasarkan mata pelajaran seperti pada gambar 11 .

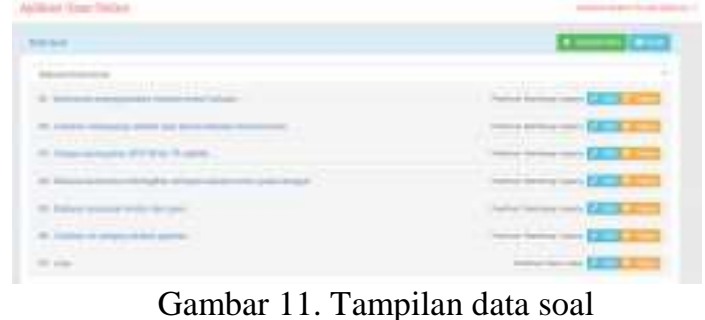

Pada menu ujian, guru dapat membuat ujian dengan memilih tambah ujian, maka akan tampil form seperti gambar 12 dan klik simpan untuk menyelesaikannya.

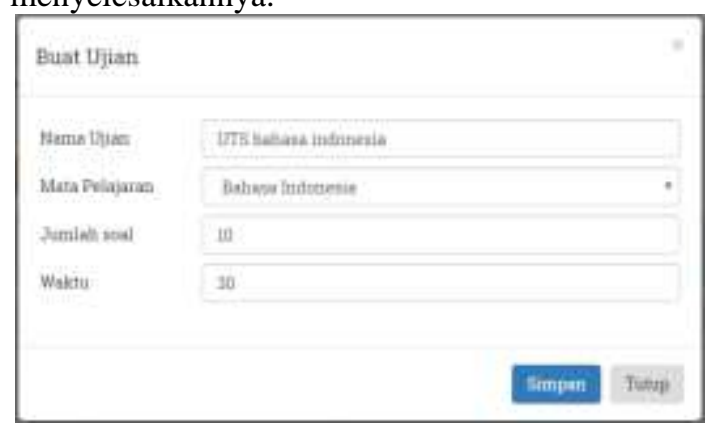

Gambar 12. Tampilan form buat ujian.

Pada dashboard siswa, hanya akan ditunjukan pada 2 menu saja, yaitu dashboard sebagai halaman beranda dengan menampilkan nama, username, mata pelajaran yang sedang diambil dan menu ujian untuk setiap siswa melaksanakan ujian yang telah diadakan oleh guru mata pelajaran.

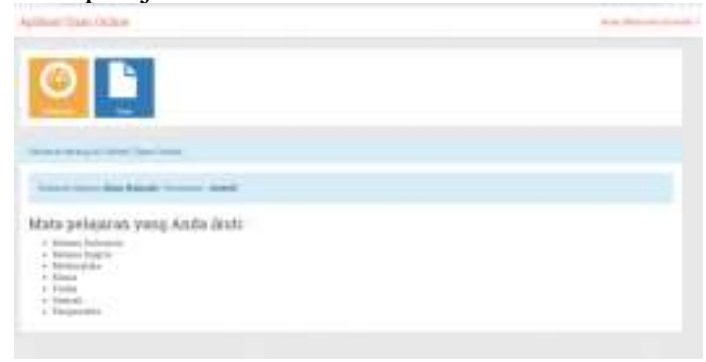

Gambar 13. Tampilan dashboard siswa.

Setelah siswa login dan mengikuti ujian yang telah dibuat oleh guru mata pelajaran, siswa harus mengerjakan soal-soal pilihan ganda secara acak dan diberi waktu sesuai kebijakan guru ketika membuat ujian. Gambar 14

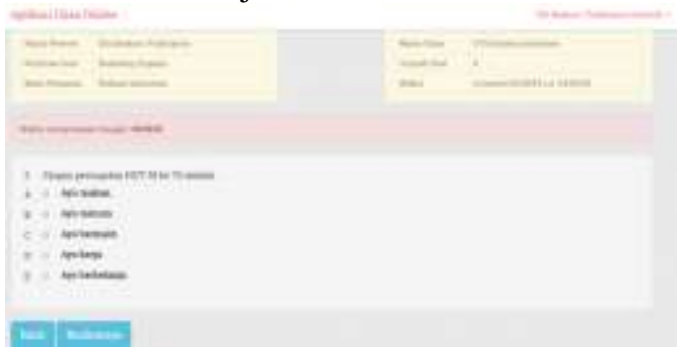

Gambar 14. Tampilan soal ujian siswa.

Setelah semua siswa mengikuti ujian, guru dapat melihat hasil dari ujian yang dibuat 
sebelumya pada menu hasil ujian. Gambar 15 menunjukan tampilan hasil ujian Bahasa Indonesia. Guru juga dapat mencetak hasil ujian dengan klik cetak yang terletak pada kanan atas menu hasil ujian.

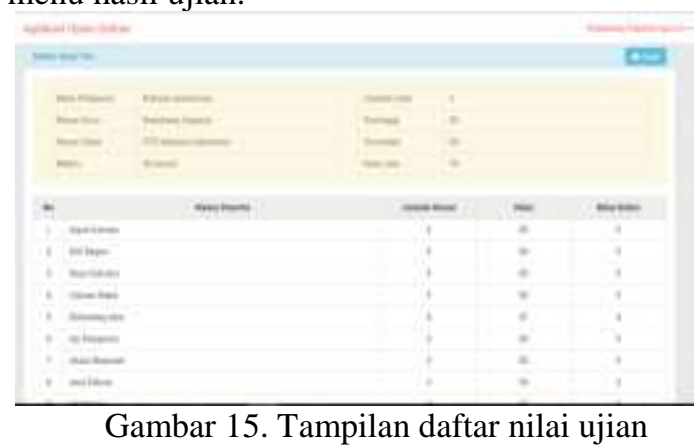

\subsection{Hasil Pengujian}

Setelah dilakukan perancangan dan implementasi ujian online berbasis web pada SMA Negeri 1 Kalirejo, tahap selanjutnya adalah dengan melakukan pengujian terhadap aplikasi. Pengujian bertujuan untuk membuktikan bahwa perangkat lunak yang dibangun memiliki kualitas yang baik dan berjalan sebagai mestinya. Melalui pengujian, kesalahan-kesalahan yang ada pada program dapat diperbaiki sehingga program yang dibuat sesuai dengan fungsinya.

Pengujian dilakukan dengan mencoba menjalankan aplikasi dari mulai admin menginput data guru dan siswa dilanjutkan guru membuat soal dan mengadakan ujian UTS Bahasa Indonesia dan 10 siswa mengerjakan soal ujian sebagai sampel. Hasil ujian dari pengujian ini dapat dilihat pada tabel sebagai berikut:

\begin{tabular}{|l|l|}
\hline Mata Pelajaran & Bahasa Indonesia \\
\hline Nama Guru & Bambang Suparjo \\
\hline Nama Ujian & UTS bahasa indonesia \\
\hline Jumlah Soal & 6 \\
\hline Waktu & 10 menit \\
\hline Tertinggi & 83 \\
\hline Terendah & 50 \\
\hline Rata-rata & 75 \\
\hline
\end{tabular}

Tabel 1. Detail ujian.

\begin{tabular}{|c|l|c|c|c|}
\hline No & Nama Peserta & $\begin{array}{c}\text { Jumlah } \\
\text { Benar }\end{array}$ & Nilai & $\begin{array}{c}\text { Nilai } \\
\text { Bobot }\end{array}$ \\
\hline 1 & Agus Irawan & 5 & 83 & 5 \\
\hline 2 & Edi Bagus & 5 & 83 & 5 \\
\hline 3 & Rani Sulistio & 5 & 83 & 5 \\
\hline 4 & Gibran Raka & 5 & 83 & 5 \\
\hline
\end{tabular}

\begin{tabular}{|c|c|c|c|c|}
\hline No & Nama Peserta & $\begin{array}{l}\text { Jumlah } \\
\text { Benar }\end{array}$ & Nilai & $\begin{array}{l}\text { Nilai } \\
\text { Bobot }\end{array}$ \\
\hline 5 & Kahiyang Ayu & 4 & 67 & 4 \\
\hline 6 & Aji Pangestu & 5 & 83 & 5 \\
\hline 7 & Alam Namsah & 5 & 83 & 5 \\
\hline 8 & Ana Febria & 3 & 50 & 3 \\
\hline 9 & Andriani & 4 & 67 & 4 \\
\hline 10 & Monika & 4 & 67 & 4 \\
\hline
\end{tabular}

Tabel 2. Hasil ujian.

Berdasarkan hasil pengujian dengan kasus uji sample di atas, dapat ditarik kesimpulan bahwa perancangan sistem aplikasi ujian online berbasis web pada SMA Negeri 1 Kalirejo bebas dari kesalahan sintaks dan secara fungsional mengeluarkan hasil yang sesuai dengan yang diharapkan.

\section{Penutup}

5.1. Kesimpulan

Berdasarkan hasil dari perancangan aplikasi ujian online berbasis website di SMA Negeri 1 Kalirejo dapat diambil kesimpulan sebagai berikut:

1. Penelitian telah berhasil mengembangkan sistem aplikasi ujian online di SMA Negeri 1 Kalirejo berbasis web dan berjalan dengan baik.

2. Pembuatan sistem ujian online merupakan sarana ujian yang bersifat online untuk mengoptimalkan kegiatan ujian serta dapat menjadi media pilihan baru dalam melakukan ujian di SMA Negeri 1 Kalirejo.

3. Sistem ujian online memberikan manfaat yaitu tidak perlu melakukan pengadaan kertas ujian dan menghemat waktu untuk koreksi ujian sehingga efisiensi dan efektitas yang menjadi tujuan pembuatan sistem ujian online dapat tercapai.

\subsection{Saran}

Penulis mengerti bahwa sistem ini belumlah sempurna dan masih banyak kekurangan, untuk itu Penulis memberi saran sebagai berikut :

1. Perlunya melakukan pengembangan lebih lanjut terhadap sistem ujian berbasis web ini dengan makin berkembangnya teknologi informasi dan jaringan, misalnya dengan pengembangan aplikasi ujian online berbasis 
android yang lebih mudah dan mobile dalam pengoperasiannya.

2. Pengguna sebagai pemakai sistem selayaknya dapat memberikan feedback demi pengembangan sistem ke depan, sehingga sistem akan selalu dapat memenuhi kebutuhan dari pengguna.

3. Dari hasil perancangan sistem aplikasi ujian online di SMA Negeri 1 Kalirejo ini masih menggunakan pilihan berganda, sehingga masih perlu pengembangan untuk menambah fitur aplikasi dalam jenis soal esai.

4. Perlunya menambah fasilitas backup database pada program, hal ini sangat penting untuk mencegah kemungkinan kehilangan dan kerusakan data yang disimpan.

\section{Daftar Pustaka}

[1] Muhamad Son Muarie. 2015. Rancang bangun system ujian online pada smp negeri 8 sekayu. Jurnal TIPS. Politeknik Sekayu. Volume II. Hal 28-40. Maret 2015.

[2] Julianti, M. Ramaddan. Petrus Silalahi. 2015. Perancangan Aplikasi Ujian Online Berbasis Web Study Kasus di STMIK Bina Sarana Global. JURNAL SISFOTEK GLOBAL. Vol. 5 No. 2. Hal 91-94. September 2015

[3] APJII. (2016). Penetrsai \& Perilaku Pengguna Internet Indonesia. Di download dari www.apjii.or.id/survei2017/kirimlink/. (24 Desember 2017 dalam bentuk e-book)

[4] Pratama, I Putu Agus Eka. 2014. Sistem informasi dan implementasinya. Informatika: Bandung.

[5] Ni Wayan Sumartini Saraswati, dkk., (2015). Sistem Ujian Online Berbasis Website. Jurnal S@CIES STMIK STIKOM INDONESIA. Volume 6, Nomor 1, Oktober 2015.

[6] Kadir, Abdul. 2008. Dasar Pemrograman web Dinamis Menggunakan PHP. Andi Offset: Yogyakarta.

[7] Arif, M. Rudiyanto. 2011. Pemrograman Web Dinamis Menggunakan PHP \& $M y S Q L$. Andi Offset: Yogyakarta.

[8] Simarmata, Janner. 2010. Rekayasa Perangkat Lunak. Andi Offset: Yogyakarta.

[9] Julianti, M. Ramaddan, Petrus Silalahi. 2015. Perancangan Aplikasi Ujian Online Berbasis Web Study Kasus di STMIK Bina Sarana Global. Jurnal SISFOTEK GLOBAL. Vol. 5 No. 2, September 2015.

[10] Safaat Nazruddin H. 2011. Pemograman Aplikasi Mobile Smartphone dan Tablet PC Berbasis Android. Informatika: Bandung. 